\title{
"Bananas are for Women, Coffee is for Men": Gendered Narratives of Agricultural Histories on Mount Meru, Tanzania
}

\author{
Beth Ann Williams ()
}

\begin{abstract}
The history of coffee cultivation on Mount Meru in northern Tanzania has been narrated by men and most scholars as a tale of extraordinary achievement and unfortunate decline. Meru women, however, associate coffee agriculture with gender inequality and social disorder. Complicating narratives of cash crop agriculture as a straightforward communal good, Williams uses oral histories to explore alternative renderings of Meru agricultural history, centering memories that highlight coffee's role in reifying patriarchal power. Women's concern with labor exploitation and emphasis on relational integrity challenge our understanding of what coffee represents in Meru history and our ideal models for pursuing sustainable growth through cash crop commodities.
\end{abstract}

Résumé: L'histoire de la culture du café sur le mont Meru, dans le nord de la Tanzanie, a été racontée par les hommes et la plupart des érudits comme une histoire de réussite extraordinaire et de déclin malheureux. Les femmes Meru, cependant, associent l'agriculture du café à l'inégalité des sexes et au désordre social. Compliquant les récits de l'agriculture commerciale comme un simple bien commun, Williams utilise des histoires orales pour explorer d'autres interprétations de l'histoire

African Studies Review, Volume 65, Number 1 (March 2022), pp. 143-165

Beth Ann Williams is a postdoctoral scholar at Florida State University in the Department of Religion. Her work explores histories of Christianity, gender norms, and community life in modern East Africa. She teaches courses related to African history, women \& gender, qualitative methods, and African/Africana religions. E-mail: bwilliams10@fsu.edu

(C) The Author(s), 2022. Published by Cambridge University Press on behalf of the African Studies Association. This is an Open Access article, distributed under the terms of the Creative Commons Attribution licence (https:/ / creativecommons.org/ licenses/by/4.0/), which permits unrestricted re-use, distribution, and reproduction in any medium, provided the original work is properly cited.

doi:10.1017/asr.2021.120 
agricole des Meru, en mettant l'accent sur les souvenirs qui soulignent le rôle du café dans la réification du pouvoir patriarcal. La préoccupation des femmes concernant l'exploitation du travail et l'accent mis sur l'intégrité relationnelle remettent en question notre compréhension de ce que le café représente dans l'histoire des Meru et nos modèles idéaux pour la poursuite d'une croissance durable grâce aux produits de la culture commerciale.

Resumo: A história do cultivo de café no Monte Meru, no norte da Tanzânia, tem sido contada pelos homens e pela maioria dos académicos como uma história de extraordinário sucesso e de um posterior e lamentável declínio. As mulheres de Meru, porém, associam as plantações do café à desigualdade de género e a distúrbios sociais. Williams complexifica as narrativas sobre as colheitas agrícolas comerciais enquanto um bem comum inquestionável, recorrendo a histórias orais para explorar outras perspetivas da história da agricultura em Meru. Coloca assim no centro desta história as memórias que destacam o papel do café na reificação do poder patriarcal. A preocupação das mulheres com a exploração laboral e a ênfase que atribuem à integridade das relações desafiam o nosso entendimento daquilo que o café representa na história de Meru e os nossos modelos ideais para alcançar um crescimento sustentável através das matérias-primas provenientes das colheitas comerciais.

Key Words: gender; Tanzania; Meru; coffee; bananas; historical memory; agricultural development

(Received 20 January 2021 - Revised 09 October 2021 - Accepted 15 October 2021)

\section{Introduction}

On the slopes of Mount Meru in northern Tanzania, banana leaves of vibrant green shade the darker branches of coffee trees below. Underground, banana roots protect the soil from erosion and provide complimentary nutrition to support the health of the coffee cherries. These two crops have grown together on the mountain since the introduction of coffee cultivation in 1902. Despite the plants' reciprocity, however, coffee has received the bulk of attention from local leaders and regional scholarship, even as bananas have consistently provided subsistence and sales across the twentieth century. This pattern was clearly articulated in oral histories told by women on the mountain. They used the crops as a metaphor to critique local patterns of agricultural profit, in which men controlled large income producers such as coffee while women were limited to the smaller gains from subsistence crops such as bananas. Stories about bananas and coffee contain insights into gendered histories of inequality and resilience. Listening to women's memories reveals a different account of something that previously looked straightforward, the agricultural history of Mount Meru.

Historians of Meru, as well as local men and foreign aid workers, have related coffee's introduction to the mountain as one of straightforward 
progress that brought higher standards of living and modernized community infrastructure. ${ }^{1}$ In their telling, people grew coffee for export markets, used the profits to build better homes, schools, and hospitals, and improved life for everyone (Baroin 2007; Mungure 2004; Spear 1997). This is a story that makes sense from the perspective of capitalist development, where increasing community wealth is assumed to raise standards of living generally. Under the surface, however, the straightforward gains of the Meru coffee economy appear much more twisted and complex.

Meru women associate coffee with progress but also hard work, exploitation, and contentious relationships. Women cultivated coffee, but they were largely cut off from decision making about its profits. Some benefited from fathers who supported their education or husbands who built them modern homes, but they did not directly control the cash from the crop. Instead, women relied on small earnings from selling bananas and other crops they interplanted with the more profitable coffee trees. When coffee was booming in the mid-twentieth century, women invested, by necessity, in a different economy, one that prioritized reliability and relationality over market value. That alternate economy became vital to the Meru community in the 1970s and later, as coffee declined in value. The story of coffee in Meru is one of progress and failure, but what failure means depends on whose perspective is in the foreground. The economic decline of coffee income was, from the perspective of women, not a disaster but rather an opportunity to move beyond gendered patterns that undervalued their labor and subsistence crops like bananas.

Women explain the shift from coffee to a more variable economy as a move from "big" money funneled directly to men to "small" money earned by women. The alternative perspective women present can also be conceptualized through contrasting big and small histories. Erika Larsson, drawing on Veli-Pekka Lehtola's indigenous histories of Sweden, argues that focusing on community perspectives and embodied, individual "small histories" raises different analytical possibilities than "'big histories' of colonial circumstances and contradictions with outsiders' societies" (2020:6). This article uses women's life histories to highlight a more personal, variable, and holistic vision of Meru's agricultural history. It showcases the feminist view that women-centered stories help us rethink solutions to inequality by bringing concerns such as community well-being and ecosystem health into economic decision making (Glazebrook \& Opoku 2020; Howland et al. 2020). Attention to gender opens, for example, conversations about interhousehold economies, patterns of decision making in agricultural communities, and the continued importance of subsistence-oriented labor across Africa (Sachs 2019; Phillips 2018; Mbilinyi 2016; Clark 2003). The small activities of women in Meru sustained family life before, during, and after coffee's heyday in the mid-twentieth century. Attending to the small histories told by those women populates broad stories of colonial economics with local actors, bringing relational, affective dimensions of economic patterns into focus. 
In addition to deepening our understanding of Meru history, the case of coffee and bananas demonstrates specific ways in which cash crops, and the colonial and neocolonial economies in which they are nested, can create social inequalities even as they contribute to financial prosperity. This critical perspective has been a deeply gendered one within the scholarship on agricultural development in Africa. Meru's coffee economy fits the historical patterns of African cash crop experiences. Often launched by colonial regimes, crops such as coffee were introduced alongside political systems that reified male authority and economic privilege while shutting women out of formal religious, political, and social leadership. Colonial officials' association of cash crops with males and food crops with females contributed to the marginalization of women in development across much of Africa (Mbilinyi 2016; Boserup 1970). Studies of gender and agricultural labor across Africa have argued that investment in cash economies reduces collaborative production within families, prompts men to leverage their control over land to expand cash crops at the expense of subsistence crops, changes the balance of power within households, and strains relationships between spouses (Dinani 2019; Sachs 2019; Konings 2012).

My attention to bananas and their discursive relationship to Meru's gendered agricultural landscape emerged out of my conversations with women. I was conducting oral history research for my dissertation, which explored the relationship between religiosity and womanhood in the twentieth century. ${ }^{2}$ It was during my interviews that I first heard about coffee and bananas as a locally resonate idiom of gender inequality. Variations of the sentiment that "bananas are for women, coffee is for men" came up in six separate conversations, enough to spark my interest in the community histories of the two crops. Oral histories, and the stories they contain, provide a vivid account of women's views on labor and gender relations on the mountain. But they have limits. For example, women's perspectives tended to discount the role of men's labor, an ironic counterpoint to women's invisibility in men's histories. At the end of the day, this article analyzes memories and discourse about gendered economic pasts. Though there are lessons for broader economic and development policies in them, the stories at the heart of the piece cannot, and were never meant to, represent the full complexity of Meru's economic realities. What they do provide is a striking, sensitive portrayal of life at its roots in a northern Tanzanian community as the people there met and managed a host of historical challenges.

This article starts with the story of coffee's role in Meru history as told by local men and historians of the district. In the second section, we plow that same ground from the perspective of the women, exploring parallel stories of women's relationship to coffee and problems with histories that discount "private" experiences of "public" economic developments. Finally, we move beyond coffee to explore women's connections to bananas and other subsistence crops, which in the 1980s moved from the margins of Meru economic tactics toward their center. This tri-part structure makes two related 
arguments. First, women's histories of coffee challenge easy narratives of cash crop development, highlighting the importance of histories from below and gendered labor analyses to producing accurate accounts of African history. Second, the alternative economy of mixed-agriculture and small-scale enterprise prioritized by women calls for a re-examination of development strategies in vulnerable communities. The banana economy, as described by Meru women, raises concerns beyond profit, including relationship building, moral fitness, and adaptability. It invites more robust, humanistic concerns into conversations about economic policies and development strategies.

\section{Coffee Comes to Meru: A History of Wealth and Success}

Meru men narrate coffee's adoption in the early twentieth century as a story of innovation, success, and economic development. Coffee farmers sold harvests for lump sum payments and used the money to advance their social standing by building modern homes, paying for their children's education, and sponsoring community projects. Coffee growing had become a central feature of Meru masculine provision and patronage by the mid-twentieth century. Of course, not all men had access to coffee's gains, as land on the mountain became increasingly subdivided and scarce due to population growth in the 1930s and 1940s. Men who failed to secure coffee holdings, either from an initial lack of interest or because they had sold land to wealthier neighbors, were cut out off from fully participating in masculine success and provision. These individuals, much like the women who are the focus of this piece, have been largely left out of the histories of Meru coffee production. Their absence stems in part from the fact that they were not central to the story of coffee and in part from the reality that many left the mountain altogether to herd cattle or to cultivate other crops on the arid plains nearby. For men who did participate in coffee cultivation, their relationship to the crop centered on capital, and their choices reflected decisions closely linked to value and profits. Their stories about coffee focus on the individual and communal effects of expanding cash flow in the district. Scholars such as Thomas Spear, Paul Pruitt, and Catherine Baroin have related coffee's presence on the mountain in similar terms.

The Meru area, located in Arusha region, covers roughly fifty square kilometers on the southeastern slopes of Mount Meru, an inactive volcano standing 4,565 meters above sea level. Rising out of arid plains, with Kilimanjaro just visible in the east, the stream-dotted slopes are verdant, covered with trees and an array of crops. The mountain is populated primarily by the Arumeru (or Rwa) people, who traditionally lived scattered around the mountain in family homesteads rather than in centralized village centers. Other ethnic groups in the area include the WaArusha, who also practiced intensive cultivation, and Maasai, whose cattle provided a valuable alternative source of subsistence in times of drought (Spear \& Nurse 1992).

Historically, land was communally owned by men, who also held private rights to its natural resources (Hillbom 2012b). Descent and inheritance 
were patrilineal. Supported by good soil and generous seasonal rains, Meru residents were (and continue to be) mainly farmers. Before they began to cultivate coffee, they focused on subsistence crops, primarily bananas, maize, beans, and millet, with many families keeping a few cattle or other livestock on less fertile land off the mountain. Despite their proximity to northern Tanzanian caravan routes, there is little evidence of trade or substantial connections beyond their Arusha neighbors until the arrival of German missionaries in the early twentieth century (Spear 1997:32-33). With the Lutheran Leipzig missionaries came coffee and expanded colonial interference in the region.

German, and later British, officials generally encouraged coffee production on Mount Meru, though European settlers sharply opposed it for fear of competition with their own coffee production. The crop was ideally suited for the mountain's high altitude, rich soil, and relatively small temperature variability. An extensive local system of irrigation furrows and relatively consistent rainfall ensured that the large amount of water needed for cultivation and pulping beans was available (Hillbom 2012b). The earliest adoptors of coffee farming on Meru were Christians. Young men were paid one shilling a month to work part-time among the Nkoaranga mission compound's coffee trees. ${ }^{3}$ Their work and income enhanced both their knowledge of and willingness to try the new crop despite its novelty, labor requirements, and slow maturation. By 1907, early Christian converts were planting coffee on their own land, and the mission farm was harvesting one and a half tons of coffee annually. In 1924 there were over 50,000 coffee trees on African-owned farms around the mountain (Spear 1997:139). Coffee farming was not without challenges, however. Many men who had the chance to plant coffee trees in the 1910 s and 1920s initially opted to develop other, more immediately profitable, crops such as onions. Coffee trees took several years to mature and required large quantities of water, both for irrigation and for processing the coffee fruit to extract the beans after harvest. Additionally, until the railroad was extended to Arusha in 1929, Meru growers were dependent on irregular access to markets in Moshi or unprofitable international schemes to sell their harvests (Spear 1997:142).

As the area's population grew and demands on both land and water increased, mountain residents increased their investments in intensely managed farms (Hillbom 2012a). Intensified land use was spurred in part by the "iron ring" of colonial land alienation, with a protected forest reserve in the higher altitudes and settler plantations on the mountain's lower slopes (Spear 1997). On their own land, however, Meru planters consistently ignored both government interventions and settler agitation against their coffee production. Their independence was bolstered by colonial officials' admiration for local productivity, the inaccessibility of many mountain holdings, and their own economic success. It helped as well that Meru farms were located farther up the mountain from settler plantations and thus could not be cut off from water sources (Spear 1996:223-25). Even as they slowly experimented with introducing coffee, farmers continued to grow maize, 
beans, and onions and to gather milk for sale in Arusha and to migrant plantation workers. In the 1940s, onion sales brought between 100 and 160 shillings annually in profits, compared to an average of 91 shillings for coffee. The historical complexity of Meru's agricultural economy has been largely forgotten by local histories of coffee, which represent the booming years of the 1950s and 1960s as the standard coffee experience. In reality, it took several decades for coffee production to reach its peak in the area.

As the century progressed, the fortunes and prestige of coffee cultivation grew, as did Meru men's investment in the crop. After crashing during the Depression era and effectively bankrupting settler farmers, coffee prices rose steadily in the 1940s, and growing numbers of Meru men planted their own trees. Eventually most men in the "coffee belt" between 4,000 and 6,000 feet up the mountain grew one to three acres of the crop, often interplanting trees with bananas, corn, and beans. In 1938 there were 807 recorded coffee cultivators among the Meru. By 1965 that number had grown to 6,603, representing almost ten percent of the entire population on the mountain (Baroin 2007:90). In the 1950s, coffee was without question the dominant crop. ${ }^{4}$ Though the 50 s represented the high point of coffee profits for Meru farmers, the crop continued to yield good returns throughout the 1960s. In 1964, a farmer who sold two to three acres worth of processed beans could expect to receive around 1,000 shillings a year for his crop (Moore \& Puritt 1977:106). Following independence, Tanzania's socialist government sought to ramp up coffee production through cooperatives, though with limited success (Hydén 1980). Meru coffee growers were spared the disruptive force of the country's infamous "villagization" policy due to its dense population, economic prosperity, and robust political connections. The real decline of Meru coffee production started in the 1970s, when a combination of global price fluctuations, aging trees, and unfavorable government policies prompted greater variability in Meru families' farming outputs.

Successful coffee farmers displayed their wealth in highly visible consumption and lifestyle changes, including building modern cement homes with tin roofs, wearing European clothing, and drinking scotch rather than the local alcohol (Moore \& Puritt 1977:92). These kinds of performances were a common feature of generational tension and gender performance in many African communities during colonial rule, as people tested new routes to adulthood and respectability. In Meru, land scarcity and a growing cash economy meant that Christian coffee farmers represented a new model for attaining masculine prestige and status (Spear 1997). The early ties between missionaries and coffee farming tied the crop closely in people's minds to cultural shifts in the forms and functions of local community leadership. Elders in the early decades of the twentieth century performed their authority by settling local disputes, holding traditional positions, and arranging marriages for their kin (Moore \& Puritt 1977). By mid-century, Christian coffee farmers had amassed their own networks of dependents, but they displayed their wealth differently by investing in new institutions like schools, churches, and cooperatives. Over time, a relatively small group of elites 
leveraged their education, connections with the church, and cash profits to assume political and social power in the Meru area.

The success that resulted from the cultivation of coffee made the Meru one of the richest communities in Tanzania. For many men, that system provided material wealth and a sense of purpose. They were involved in a prominent export industry, producing a luxury good that facilitated their ability to perform masculine provision by paying school fees, building homes, and contributing to community fundraisers. In their memories, successful Meru men associated coffee with community development and improvements in infrastructure such as paved roads, bridges, hospitals, and houses. Moses Ndosi, a retired doctor, linked the crop to changes in home construction. "Every aspect of life [changed]. Before the [19]50s every house in this village was a little hut thatched by banana leaves from top to bottom. The Christians, when coffee was a valuable crop, they were the first ones to build houses and improving the setup." The image of changing houses also loomed large in the mind of Robert Kitomari, a former chairman of the Meru coffee cooperative. Born in 1925, he also shared a story of progress, highlighting the installation of a roasting facility and referencing improved home styles, education, and healthcare.

All the Meru people used to stay at one place and sell coffee together. I became the chairman...A factory was built. All the land for the factory, I am the one who looked for it and bought it. People raised money, we bought land... Children were taken to school, hospitals increased. It's just the coffee.

In contrast to these rosy memories, men who lacked enough land to access coffee profits were unable to participate in this development. In the 1950s and 1960s social inequality increased in Meru, spurring out-migration into drier lands around the mountain, especially by younger sons (Larsson 2001:112). ${ }^{5}$ Successful men also omitted in retrospect the fact that coffee wealth put them at odds with president Julius Nyerere's socialist agenda. The country's venerated founding father did not find many supporters among the local elites, though few publicly voiced their views. Ultimately, despite efforts to reallocate land on the mountain and some exclusion of Meru landlords from ruling party positions, the socialist era generally solidified rather than degraded the control of a relatively small group of wealthy men (Moore \& Puritt 1977:119; Larsson 2001:408).

By the 1970s, however, the fortunes of coffee on Mount Meru were deteriorating due to aging coffee plants and fluctuating prices. Coffee's global value increased dramatically from the late 1960s through the 1980s, but the real value paid to Tanzanian producers swung wildly from year to year (Lofchie 1989). The International Coffee Agreement of 1962, which had maintained floor prices during the Cold War, collapsed with the socialist bloc, leading to lower prices. Following independence, from the late $60 \mathrm{~s}$ and 
into the 70s, Tanzania's socialist government sought to ramp up coffee production through cooperatives, though with limited success, given their somewhat adversarial relationship with Meru's landowning elites (Hydén 1980). Government investment in quality control and infrastructure declined through the 1970s. The combination of uncertain prices, unfavorable government policies, and declining yields led to a widespread abandonment of coffee cultivation in Meru beginning in the 1970s and continuing through the twentieth century (Butovskaya et al. 2016; Hillbom 2012a).

Many men in Meru had committed to the coffee economy-and the Christianity, commerce, and cash that accompanied it-as the ideal path to African manhood. Now that path, or at least the coffee part of it, was no longer viable. It also shifted gendered patterns of financial responsibility as women's trade increasingly supported their families' financial needs. The implications of coffee's decline for Meru masculinity were not a subject that men felt comfortable discussing directly in interviews. It emerged around the edges of conversations, often accompanied by uncomfortable laughter. Martha Sarakikya, who grew up on Meru in the 1960s, reflected on the shifting economy of the area.

\begin{abstract}
And now things have turned around and are very difficult for the men. To go sell bananas was demanding for men, because there wasn't much there. He owns the shamba [farm], the cows, the coffee: those are big things. But now coffee was no longer there. And now the bananas are what is bringing in the cash. So it is very difficult for men now.
\end{abstract}

Martha used the language of difficulty to express her sense that men were not satisfied with the smaller earnings from bananas and other agricultural products in the aftermath of the coffee boom. Eunice Pallangyo, another Meru resident, talked about women taking over the local economy, but she quickly clarified that the changing gender pattern was not something people "said publicly because it is kind of a shame." A younger man named Stanley Mana echoed this assessment. He laughed about the situation but stated that men in his community wanted to be in charge rather than perceived as performing historically feminized tasks. "It's the African character these things. (laughter) The character of African men. They only want to command. To sit high. To walk with other men on the road. They don't want children. They don't carry bags or children." If men would not carry the children, then it fell to women. Retired teacher Margaret Mbise summed things up bluntly. "You find men are not happy. If they are not working somewhere, they are not happy, and it's the women who are taking care of the family." Margaret, unlike some other women, acknowledged the relative loss of purpose some men experienced with the end of the coffee boom. She also pivoted straight to the heart of the issue for many women. The reasons for coffee's decline were less significant than what happened afterwards, when women started "taking care of the family." 


\section{A Different Coffee Story: Gender and Resource Distribution on Mount Meru}

The story of coffee as told by women was more complicated than the straightforward progress narrative recorded and remembered by men. Gendering stories of coffee changes the scale at which we explore the crop's impact and meaning. Masculine histories of the crop prioritized its impact on the Meru landscape and overall community development. Scholars, former coffee farmers, and government officials talked about paving roads, building schools, and establishing a hospital when they discuss the impact of the crop (Mungure 2004; Spear 1997; Moore \& Puritt 1977). Everything about coffee looked good from the panoramic view of the economic winners. But talking to marginal beneficiaries of that improved economy revealed inconsistencies in the story. Women's relationship with coffee production and profits were more patchwork, varying from person to person. Perhaps even more vitally, women's memories of coffee agriculture highlight a wider range of experiences with the crop, from the labor that produced it to its impact on social relationships on the mountain. Bringing women's voices into the histories of coffee in Meru offers a more holistic perspective on coffee's presence in Meru, one that acknowledges labor inputs and social impacts as well as economic benefits (Sachs 2019; Mbilinyi 2016).

When women talked about coffee, they moved under the surface of communal gains to highlight differences in control and decision-making rather than outcomes. Men discussed the impact of coffee as a communitywide social good. They highlighted generalized development in ways that flattened the economic and social landscape of Meru into a single story of progress. Women, on the other hand, emphasized masculine control over coffee proceeds. Men were members of the coffee cooperatives and received the funds from sales that emerged out of family labor, a pattern built into the foundations of coffee's presence by the missionaries and colonial officials who introduced it. Meru women certainly did experience benefits from smallholder coffee profits. They lived in the new, modern houses coffee helped build. They walked or rode motorbikes along the area's newly paved roads to visit friends or go to church. Their children wore uniforms, read books, and attended schools paid for with coffee profits. But when you talk with women about coffee, those were not the things they associate with the crop. Women talked about the actual labor of producing coffee, sharing details about early mornings spent processing the harvested cherries into beans. Even more, they talked about the fact that coffee profits went straight to the men.

One irony embedded in men's narratives about the wealth of coffee is that women and children's labor, invisible in their memories, was central to coffee's production and success. While men rarely mention the actual work of producing coffee when discussing the crop, women foreground the mechanics of the labor coffee required. Many female interviewees grew up working on their family's coffee farms. Their stories included unsolicited descriptions 
of the timing, patterns, and types of work involved in coffee production. Ensuring a consistently productive crop required appropriate spacing and shade, regular pruning to coax new fruitful branches to emerge, strategic fertilizer application, regular weeding, and a harvest extended over a long period as the fruit matured intermittently. Men were generally in charge of the initial tree planting as well as the maintenance work, but women contributed regularly to weeding, picking, and processing the crop. During harvest, individual cherries were picked by hand as they matured.

Even women who benefitted from the coffee income linked coffee and labor in ways that men did not. The constant demands of agricultural work on the mountain, not just coffee agriculture but of life in general, was regularly on display in women's narratives. Margaret Mbise was born in 1950; she remembers running to school across green paths of coffee and bananas. As a middle schooler in the early 1960s, she walked over forty minutes back and forth to a coed school that provided dorms for boys but not girls. When she returned home each night, she contributed to household chores. For Margaret's family, living surrounded by her father's "big coffee farm," those chores included a range of tasks for managing the crop. During harvest, she recalled staying awake until after 10 p.m. removing the outer skin from coffee fruits with their one machine. The children would then rise early to soak the deskinned cherries in the river before school. School was important, but coffee came first. As Margaret put it, "My father used to tell us, you have to go to the river to take the coffee. Then you go to school. He was serious." Here we see the complexity of Margaret's relationship to coffee. The crop supported her family's well-being and her own ability to attend school, an investment that facilitated her future career as a teacher. She spoke without resentment about her contributions to that prosperity, and she seemed to have a good relationship with her father. Yet, later in our conversation she also discussed gender inequality in Meru relationships through the lens of coffee and bananas. Despite the ways that she personally benefited from the crop, Margaret still understood coffee as something that was "for men." Without the memories of coffee labor shared by Margaret and other women like her, it would have been easy to overlook the labor involved in bringing coffee profits to Meru.

Women's stories about working with the coffee trees underscored the sense of disassociation and distance they felt from the coffee gains. Separation from coffee profits meant that women were also denied the community regard that accompanied cash contributions and purchases. In the midtwentieth century the cash economy was relatively nascent in Meru. Access to cash was associated with new opportunities linked to missionaries and colonial structures. Cash was an important element in power struggles between old and young men negotiating for community authority, and women were left out of that debate altogether. A teacher named Elli Nasari explained, "Men used to have coffee farms. In the past, profit from farm products was there so men used to have money. Men are the ones who owned money. Women were not given money." When Nasari said that women were 
denied access to money, she communicated both that they were not able to access consumer goods and that they were shut out of the wider community debates over power. Women felt alienated from the profits they helped create as well as the role those profits played in shaping community leadership. Born in 1951, Veronica Ezekiel, a farmer with eight children, discussed the ways that Meru women were disenfranchised within the wider Meru economy from both performing business and accessing farming profits. "Only a few women in the past did business. Business was done by the Chagga and Pare. Meru women farmed and raised cows. They raised coffee. The men went to get the money. They gave you some money and you thanked them." Meru women raised cows and coffee. The men received the money. If they were willing, they would pass some to women, who should in turn express gratitude. Thus, even when men used money well, for example, to support their families, it was part of a system of unequal power between the genders.

Men's control over coffee profits entrenched historic patriarchal patterns in the Meru community. In the early twentieth century, men pursued multiple wives because they benefited from their agricultural labor. Men prepared the soil and cleared fields for planting, then women planted, weeded, harvested, and processed crops. By the 1940s, technology upgrades such as tractors and oxen plowing brought men into agricultural labor in new ways, but women's labor burden did not diminish overall, as the women remained responsible for annual crops and gathering fodder for the cattle (Spear 1997). Meru's local coffee economy was part of this pattern, which also included prioritizing male access to land rights, education, and community leadership. Coffee, however, surfaced with vivid specificity in women's memories.

Born in 1953, Elizabeth Urai recalled working on her family's farm and harvesting coffee, but "Once the harvest was over my father received all the store keys. Therefore, he can give us what he wants. So, my mother had nothing." Elizabeth linked her specific memory about the keys to her father's influence over the family's wealth. A small business owner named Helena Pallangyo, born in 1983, told me that in her mother's time, “There wasn't anything for the women. The job was all for the men. If a child was getting married... the men were selling coffee. It wasn't bananas. It was all coffee. The dad would get money and would not return home for [a] time. That money didn't go to the house for the children." Her reference to marriage called out the role of men in arranging the future of their children as well as their ability to benefit from bride wealth. With the responsibility to pay for the "big things" of life came the right to profit and benefit from those things. The way that coffee money moved through Meru increased the ability of men to act as patrons and providers, strengthening male control over the families who helped to create those profits.

Women's moral judgements about men's use of coffee profits represented another contrast to the positive progress narratives that dominated standard stories of the crop. Women judged and gossiped about men's use of coffee funds, challenging their moral fitness to manage family and 
community resources. They complained about how men misused the profits, wasting them rather than supporting their families. Men's misappropriation of coffee money was most commonly linked to spending on meat, beer, and other women. The historic association of coffee production with the missions is especially ironic, as women deployed Christian judgements against the coffee-selling men's drinking and perceived sexual misconduct. The multiple layers of women's stories about coffee came together in an interview with Rita Kinagazi, a Meru teacher born in 1957:

By that time coffee was a great cash crop and coffee money was only for men. So, the woman could assist in farming, in picking coffee, in grinding it, in washing it, in drying it. And they could take it together to the cooperative union. After they have sold, the woman could be going back with the empty bags. The man could take the money and go to the meat shops where they were roasting and eating there. He could come back with nothing. He could eat the meat with other women. There was no good life at all.

Rita clearly identified coffee in her community as a man's crop, although it was supported by women's labor. She also explicitly linked those gendered patterns of ownership and profits to gender inequality in Meru community life, "But the women they thought that they deserved what they were getting. 'I am a woman. What a husband does he has to do because he is a man.' There is what we call mfumo dume [patriarchy]. The men are pressing the women. That is how life went." In Rita's version of the coffee story, there were profits but no "good life," as coffee served only to reproduce and strengthen gender inequality in Meru families. Her explanation echoes scholarship on other Tanzanian regions where male dominance of cash income increased marital tensions and contributed to a particularly gendered experience of insecurity (Dinani 2019).

For women in Meru looking back on the mid-century situation, coffee profits were as much a cause of moral decline and dissipation on the mountain as they were of development. Their stories of wastrel coffee owners and desperate women contrast the image offered by Meru men of coffee as the great crop of Meru progress. Men deployed coffee profits as a tool in masculine debates over patronage, community authority, and respect. Women did not appear in those contests, but they lived through them and, apparently, judged them. Men were not necessarily intentionally or selfconsciously embarking on a damaging, patriarchal path. Rather, as colonial disruptions and economic change upended older expressions of masculine identity, control over women and the profits their labor helped secure were increasingly important to ensuring men's prestige and public respect.

In recent times, widespread ideas about ideal patterns of gender control and access have shifted. Now, many in development and NGO circles champion getting money directly into the hands of the women, who can be "trusted" to spend it on their families. In this context, women's stories of male wastrels can feel like a well-worn trope, and it is likely that the women's 
memories did play up the times when money was tight or the father came home drunk. However, Paul Puritt, an anthropologist conducting fieldwork among the Meru in 1964, observed that "eventually most of the cash realized in Meru found its way to the beer shops and bars. Drinking was almost a fulltime activity for most old men, and many young men and women" (Moore \& Puritt 1977:97). Puritt's observation highlights the variability of women's behaviors. Nevertheless, it was clear in the course of my interviews that women perceived a sharp contrast between men's historic opportunities and their own.

Shut out of the major earning possibilities and thus the prestige of the mid-twentieth century, women turned to different methods for claiming community standing. In an ironic twist, given the association of coffee with missionary gender ideals, Meru women, in what was becoming an increasingly Lutheran community, called on church ideals of family provision, sexual fidelity, and humility to bolster their own sense of personhood and self-respect. Their narratives of self-worth emerged in large part in response to the perceived failures of men. Male authority was permeable and open to judgements of moral fitness and worthiness. Men had the capacity to improve life. Some did so by investing in education and other family goods, but some did not, and that opened room for women to maneuver. Overall, women encountered coffee as a mixed bag in which generalized wealth may or may not have an effect on their lives, depending on the character and priorities of the men around them. Yet women were not passive in the midst of this coffeedominated economy. Even as coffee brought big profits, women continued to pursue their own small endeavors, selling bananas, eggs, and milk. Women knew they could not count on coffee to support them, and it turns out that was a good thing.

\section{A Story Not About Coffee at All: Bananas as Subsistence and Provision}

Women did not view coffee's demise with the same shame and regret expressed by men. For Meru women, the story of coffee's decline was instead one of resilience, action, and unexpected success. It was a story in which they, and bananas, took center stage after years of being left at home and unappreciated in the household economies. Throughout coffee's heyday in the mid-twentieth century, banana cultivation and other vegetable farming continued as before on the mountain. Most families did not take bananas to market, though a woman might sell some from her home. Other crops such as onions, maize, and beans were cultivated for both subsistence and sales, depending on a given family's land and preferences.

As coffee's overall value declined, banana, milk, and other vegetable sales gained relative importance within family budgets. This change helped diversify Meru households' modes of provision, and the women who managed these crops often prioritized security, flexibility, and small gains above the bigger payouts of export cash crops. The ascendent role of bananas and other small crops in the economic landscape of the 1970s and 1980s represented 
more than economics; it paralleled changes in how women understood their value and role in family provision. Much as coffee's rise and fall were closely tied to the fortunes and meaning of masculinity on the mountain, the emerging value of bananas to local families paced women's growing capacity as cash earners and financial decision-makers. In the 1970s and the decades that followed, women in Meru developed greater confidence in their abilities, earning capacity, and organizational aptitude. They tell the history of banana sales as a story of moral and social progress.

Bananas have a long history in East Africa. On Mount Meru they have been a mainstay of food cultivation since at least the nineteenth century. In 1887, an Austrian explorer described banana plantations covering "the slopes of the mountain in every direction" (Spear 1997:32). Banana trees reliably produced high yields year after year and came in over twenty varieties that could be eaten or brewed and interplanted with other crops. In short, they provided a dependable, nutritional source of food that required relatively little work input. Banana production was reliable, in contrast to the high profits and risks of coffee. Bananas were also less risky because they required less investment. Whereas coffee cultivation required that the grower pay transport costs (for such expenses as gasoline) and deal with government regulations, growing bananas was much simpler; bananas could be sold nearby and carried by hand or head to local markets. Abraham Kitomari, a Meru village chairman, told me, "Every day the family is here. It must be provided for every day. Not one day can pass without eating. The bananas and cassava are here. We eat. And life continues." Bananas and other garden crops sustained life on the mountain, and so they were closely associated in people's minds with Meru society and culture.

Bananas were considered women's crop; women tended the trees and managed the sales and profits of the plant. Several women told me that their mothers sold bananas to provide them with "pocket money" for small purchases. Women learned about bananas from each other, absorbing patterns of cultivation from their mothers and neighbors. Sharing banana plants, which reproduced by propagation, fostered reciprocity and relationality between neighbors (Arens 1979). The widespread presence of bananas meant that they never brought massive returns. Prices were kept relatively low, given that the fruits were highly perishable and faced a saturated market, another factor that promoted giving them away to friends and neighbors. Despite these challenges, women talked often and positively about the income bananas brought them. Incremental gains meant that banana sales were available on a day-to-day basis to cover the cost of purchasing processed food and other necessities. This small factor loomed large in women's minds because it negated one of the great frustrations they had with coffee, their perception that men immediately spent the proceeds (and not necessarily in good or beneficial ways). Elli Nasari, a retired teacher, contrasted the small work of female cultivation with the helter-skelter pace of coffee. "When they get money from coffee, they want to use it immediately but they don't allow you to sell ... Men feel 
ashamed to go and sit in the market, but women are not ashamed. She sells bananas and gets money and children move on with life."

As coffee declined in value and ubiquity, other crops, including bananas, became more important economically for families' cash needs and sustenance. The 1970s brought an intensification in vegetables grown for local markets as well as milk and banana sales. Bananas went from being primarily a subsistence crop to being a significant source of income in Meru. ${ }^{6}$ Whether or not bananas constituted the primary source of income for a given household, most smallholder farms on Meru, around 80 percent in 2021, produced bananas (Hillbom 2012a:661). They ate the bananas themselves, shared them with guests, and donated them to the church in lieu of tithes. Women associated the increasing importance of historically female products with changes in their mobility as well as a growing sense of purpose and possibility.

The necessity of earning cash by means other than coffee drew increasing numbers of women out from their homes and into new opportunities. This circumstance was driven primarily by financial need, but it was also bolstered by wider sociopolitical movements, including Nyerere's valorization of rural women farmers, the global women's movement, and NGO attention to women's empowerment. Elli Nasari, who reflected on banana's small gains above, also talked about the movement of women into markets, a transformation she closely linked to women's ability to have a "good life." "If you see a woman who has a good life, right now women have made a change. They can sell bananas in the market, whereas in the past it was not possible. Women were not allowed to do business. Now they have a chance, not like in our parents' generation." Women were on the move, carrying their bananas and other products to market, a pattern of female respectability that contrasted with the largely domestic expectations of earlier generations (Haram 2004; Howland et al. 2020).

This change in female mobility spurred its own share of social tension, both over the respectability of female entrepreneurship and the capacity of women to perform in business. Born in 1965, small business owner Loveness Kitio talked about how her mother did not believe that women had a head for business, because in her time they had not participated in the markets:

Right now, even when I ask my mother why we are doing business that is not successful she tells us that we are not the head of the businesses. They [women] didn't used to do business in their lives. She says that there is no one who took bananas to the market to sell. They plant bananas and that is the food for her children. If someone comes to your home and asks you to sell bananas to them [you can sell], but not taking them to the market.

Loveness did not have great wealth, but she recognized that her ability to attempt her own business ventures, and to control any profits gained from her efforts, was an improvement over her mother's relationship to money. The financial need that declining coffee income created was real, and it must have been stressful for the families living through it. Loveness and other 
women who reflect on that shift, however, emphasize not the lack of resources but rather the growing opportunities for women to seize control of their own products and income.

The economic changes Meru residents endured provided new horizons and a sense of personal ability for many women. One such woman was Rita Kinagazi, a retired schoolteacher. She moved to Meru with her husband in 1978 and reflected on her first impressions of her new home, linking the decline of men's coffee income with women's growing self-respect and awareness of their rights. "There was no good life at all... But then coffee has been disappearing. The coffee is becoming old. No more coffee. So, the difference came. And now women start to wake up. To think more of how to get money. I think that is how the changes came." Given how women judged men's use of coffee money as selfish and immoral, it made sense that their own stories highlighted their humility and re-investment in family. ${ }^{7}$

Meru women deployed ujamaa ideals of self-reliance, hard work, and community service to frame their economic endeavors. This was especially ironic in Meru, where many men subtly resisted socialist principles of redistribution in favor of consolidating their wealth and entrenching local positions. National ideals of community investment found more ready champions among local women. Betseba Pallangyo grew up in the 1960s and 1970s, raising three children on profits from her farming and one cow. She related "women's work" to the core themes of ideal ujamaa citizenship: productivity, self-reliance, and social contributions:

They raise vegetables. They teach people to farm vegetables. They teach about medicines. I was taught to farm. I raise my own vegetables. I sell them. I get money. Now women are increasing, before it was just men. Now you go to the market and see women competing. This is a difference between now and before. Right now is better. There is development. Me myself, I can educate my children.

Women mobilized small gains from vegetables, bananas, and entrepreneurial businesses to take an active role in the mountain's economy. They had not been given cash by men; they were making it for themselves.

The human-focused character of women's strategies and lives, which relied on support from other women and justified itself with reinvestment in children, contrasted with the infrastructure projects and community patronage pursued by Meru men. Whether through choice or necessity, women employed a more flexible and multifaceted economic strategy than men. They relied on informal support networks, multiple sources of income, and strategic leveraging of resources that were already on hand. One of the most valuable resources for women was other women. Elli Nasari reflected that once women saw their peers succeeding, even in attaining small gains through banana sales and other businesses, they were ready to try and learn for themselves. "You find that if she was not educated, she would feel that she is not able. But if they see the rest making it then they also want to know how, 
and once they get capital they are good to go." Tanzanian women's economic activities by the 1980s varied widely, including horticulture, embroidery, beer brewing, selling food, handicrafts, operating milk and soft drink kiosks, small livestock keeping, and fishing. Many of these activities allowed them to keep flexible hours or work from home, necessary conditions for women with young children who required constant care.

Bananas and their ilk worked well in an economic decision-making context that valued strategy and choice. The decision to consume or sell a crop depended on family needs, a particular harvest, and social obligations. This system was largely self-sustaining and invested in social reproduction as much as production, a valuable counterpoint to historic and modern investments in product chains and global networks (Mbilinyi 2016). These factors enabled individual families to adapt to a given moment's needs and opportunities. The priorities expressed by women focused on basic provision and sustaining the lives of their families. Grace Kitange, a Lutheran parish worker in nearby Moshi, described the psychological condition of women in the area:

Women know how to free themselves. They aren't in a condition to say that "I can't do that. I am just waiting for my husband to bring me this and that." Now they know that they can do things—-they are working, they are getting for their families. Now you find women who are building houses, who are driving, who are teaching children.

The increasing market activities of women was not an easy adjustment for the Meru community. The uncertainty of new resource distribution, financial responsibility, and income patterns sparked judgements and gossip as people reconfigured their shared norms and moral values. A male pastor described the shift this way: "Those things that were not held in high regard are those that are now of value. Right now, a woman takes bananas to the market and comes back with 40,000 and you at home you have nothing. She is trying for revenge. So, things have changed. It is the men who come crying in the office." The changes he referenced connect to the masculine prestige of coffee and its unintended consequence, the shame and failure felt by men who could no longer provide in the same way they had before. Eunice Pallangyo told me, "So this father because of the status cannot do this tiny business-selling vegetables. So mothers! They are doing like that (snaps her fingers)... They are very fast joining in groups, doing small business, going for exhibitions... Going to this market and that. They are out." Meru women remember the rise of bananas as a move toward female empowerment, a shift in the gendered landscape of their communities that was legitimized by their moral investment in others.

\section{Conclusion}

"It is coffee that raised this country. Houses were made out of mud and the roof was banana leaves. But coffee did away with the mud houses. Children 
were taken to school, hospitals increased. It's just the coffee. (Robert Ndeleko Kitomari, Meru coffee farmer)

Robert Kitomari was one of the most vocal advocates for coffee's benefits to the Meru community that I encountered. A former coffee farmer and chairman of the Meru coffee cooperative, he embodied the standard, triumphant story of the crop's benefits. Yet buried right in the middle of his monologue, so quick you might miss it, bananas appeared. Before coffee enabled the construction of concrete houses with metal roofs, bananas leaves sheltered the residents of Meru. This fleeting reference hints at the previously untold stories of coffee and bananas in Meru history that have been brought forward in this article. Despite the pronouncement that development on the mountain was "just coffee," we see clearly that coffee plants and the coffee economy alike were supported by a wider system of smaller crops and daily labor. This variable network was illuminated through the memories of Meru women. And we have seen how a women-centered history of labor, power, and agriculture on Mount Meru looks very different from the standard story told by Kitomari.

The story of Meru's agricultural history, as recalled by elite men and a number of early historians, celebrates the crop for the wealth and development it brought the community. This is an outcome-focused view of history, with the houses, schools, and bridges of the region speaking for themselves about the unquestionable value of the crop and its positive impact on the region. Women's histories unsettle this view of coffee and the cash crop economy as a universal good for their mountain community. Their concerns about labor and how profits were used bring questions about inequality and access to the foreground. They also infuse a largely economic discussion with questions about social values and priorities. Women's relationship to economic development was more patchwork, more complicated, as they sought to balance the demands of unpaid work raising children, sustaining relationships, and acquiring cash. Attending to their perspectives changes how we narrate history and challenges our metrics for defining success and failure in agricultural communities across Africa.

Although coffee's decline hurt the overall economic value of the Meru region, women's capacity to provide for themselves and their children through crops like bananas expanded as coffee lost its economic dominance. Women's alternative stories about coffee contain valuable lessons as Meru and other communities across Africa face economic and environmental fragility sharpened by climate change. Colonial, neo-liberal, and global infrastructures have historically invested in promoting the large gains of export crops and mono-agriculture. Women living in Meru, on the other hand, needed the week-to-week certainty that they could provide for their families. This led them to prioritize variability and relationality. They invested in the dependability of bananas and other garden crops, sustaining a multiplicity of plants in the Meru ecosystem before, during, and after coffee's ascent. I join gender scholars across disciplines to argue that women's 
interwoven attention to economic and social issues should help guide development efforts and shape metrics for economic improvement (Glazebrook \& Opoku 2020; Sachs 2019). The entwined histories of coffee and bananas on Meru show that sometimes it is the messy, tangled roots of communityfocused strategies that signal the most sustainable ways forward.

\section{Acknowledgments}

Many thanks to the three anonymous reviewers and $A S R$ editorial staff for their generous feedback on this article. Thanks as well to Caity, Kristen, Janet, and Jodie for your feedback and encouragement along the way. Finally, asante sana to the Akyoo family, Jacki, and Glory, without whom this project would not have been possible.

\section{References}

Arens, W. 1979. On the Frontier of Change Mto Wa Mbu, Tanzania. Ann Arbor: University of Michigan Press.

Baroin, Catherine. 2007. "The social impact of growing coffee in northern Tanzania." Etudes rurales 180: 85-100.

Boserup, Ester. 1970. Woman's Role in Economic Development. London: Allen \& Unwin.

Butovskaya, Marina L., Valentina N. Burkova, and Dmitriy V. Karelin. 2016. "The Wameru of Tanzania: Historical Origin and Their Role in the Process of National Integration.” Social Evolution Ẽ History 15 (2): 141-63.

Clark, Gracia, ed. Gender at Work in Economic Life. 2003. Society for Economic Anthropology (SEA) Monographs; v. 20. Walnut Creek, California: Altamira Press.

Dinani, Husseina. 2019. "Gendered Migrant Labour: Marriage and the Political Economy of Wage Labour and Cash Crops in Late Colonial and PostIndependence Southern Tanzania.” Gender E History (3): 565-83.

Glazebrook, Tricia, and Emmanuela Opoku. 2020. "Gender and Sustainability: Learning from Women's Farming in Africa.” Sustainability 12 (24): 1-20.

Haram, Liv. 2004. “'Prostitutes' or Modern Women? Negotiating Respectability in Northern Tanzania." In Re-Thinking Sexualities in Africa, edited by Signe Arnfred. Uppsala, Sweden: Nordiska Afrikainstitutet.

Heyer, Amrik. 2006. "The Gender of Wealth: Markets \& Power in Central Kenya." Review of African Political Economy 33 (107): 67-80.

Hillbom, Ellen. 2012a. "Market Institutions Benefiting Smallholders in Contemporary Meru, Tanzania." The Journal of Modern African Studies 50 (4): 657-79.

- 2012b. "When Water Is from God: Formation of Property Rights Governing Communal Irrigation Furrows in Meru, Tanzania, c. 1890-2011.” Journal of Eastern African Studies 6 (3): 423-43.

Howland, Olivia, Dan Brockington, and Christine Noe. 2020. "Women's Tears or Coffee Blight? Gender Dynamics and Livelihood Strategies in Contexts of Agricultural Transformation in Tanzania." Agrarian South: Journal of Political Economy 9 (2): 171-96. 
Hydén, Göran. 1980. Beyond Ujamaa in Tanzania: Underdevelopment and an Uncaptured Peasantry. Berkeley: University of California Press.

Konings, Piet. 2012. Gender and Plantation Labour in Africa: The Story of Tea Pluckers' Struggles in Cameroon. Bamenda, Cameroon: Langaa RPCIG.

Larsson, Erika. 2020. "Feeling the Past: An Emotional Reflection on an Archive." Journal of Aesthetics $\mathcal{E}$ Culture 12 (1): 1-12.

Larsson, Rolf. 2001. "Between Crisis and Opportunity: Livelihoods, Diversification and Inequality among the Meru of Tanzania." Sociologiska institutionen, Lunds universitet.

Lofchie, Michael F. 1989. The Policy Factor: Agricultural Performance in Kenya and Tanzania. Boulder, Colorado: Lynn Rienner.

Mbilinyi, Marjorie. 2016. "Analysing the History of Agrarian Struggles in Tanzania from a Feminist Perspective." Review of African Political Economy 43 (1): 115-29.

Moore, Sally Falk, and Paul Puritt. 1977. The Chagga and Meru of Tanzania. London: International African Institute.

Mungure, Justin Elias. 2004. "The Relationship between Church Growth and the Quest for Lutheran Church Autonomy in Meru." Dissertation, Master of Theology, Tumaini University.

Omari, Cuthbert K. 1996. "Rural Market Women in Northern Tanzania." In What Went Right in Tanzania: People's Response to Directed Development, edited by Marja-Liisa Swantz and Aili Mari Tripp. Dar es Salaam: Dar es Salaam University Press.

Phillips, Kristin. 2018. An Ethnography of Hunger: Politics, Subsistence, and the Unpredictable Grace of the Sun. Framing the Global Book Series. Bloomington: Indiana University Press.

Sachs, Carolyn E. 2019. Gender, Agriculture and Agrarian Transformations: Changing Relations in Africa, Latin America and Asia. London: Routledge.

Spear, Thomas. 1996. "Struggles for the Land: The Political and Moral Economies of Land on Mount Meru." In Custodians of the Land: Ecology E Culture in the History of Tanzania, edited by Isaria N. Kimambo, James Leonard Giblin, and Gregory Maddox. London: James Curry.

1997. Mountain Farmers: Moral Economies of Land E Agricultural Development in Arusha $\mathcal{E}^{\circ}$ Meru. Dar Es Salaam: Mkuki na Nyota.

Spear, Thomas, and Derek Nurse. 1992. "Maasai Farmers: The Evolution of Arusha Agriculture.” The International Journal of African Historical Studies 25 (3): 481-503.

\section{Notes}

1. A notable recent exception comes from Olivia Howland, Dan Brockington, and Christine Noe (2020), whose argument closely parallels my claims that gendered analysis is necessary for judging community well-being and economic impact.

2. I conducted ninety-eight interviews around the Meru district, the majority centered in the neighborhoods of Kilala and Singi'si where my two research assistants lived. Taking place in Swahili and lasting anywhere from forty-five minutes to two hours, the conversations started with biographical information about women's childhood, education, and work, which was then followed by open-ended questions related to their religious practices, views on gender, and hopes for the future. 
3. One shilling was a good wage for the time. One cow could be purchased for around five shillings (Mungure 2004:57).

4. The amount of coffee sold increased rapidly, from an average of 25 tons annually in the late 1920 s to 143 tons in the 1940 s to 2,037 tons in the 1960s (Spear 1997:139).

5. This out-migration of younger sons had lasting impacts on the area's economy, as the young men took jobs in town or set up their own small business enterprises. When crops such as bananas later developed into marketable produce, many young men lacked access to meaningful amounts of mountain land or had already invested in off-farm opportunities. Rolf Larsson's study of the Meru area (2001) found, for example, that 15 percent of the households he surveyed were "functionally" landless with less than .5 acres available to work. This meant that while some family members, predominantly women, farmed and sold produce, the family functionally depended on predominantly male off-farm income to sustain themselves. The pressurized land situation on the mountain was further heightened by the area's geography. Meru is large, but much smaller than Kilimanjaro to the east or the rolling Kenyan central highlands to the north. Its wet, relatively well-watered mountain land quickly deteriorates into dry plains that would not sustain bananas and other water-intensive crops. Opportunities for even small-scale farming outside the tightly packed mountain slopes was limited to nonexistent. This contrasts, for example, with the situation in central Kenya, where some young men have pushed into traditionally female subsistence crop farming and sales (Heyer 2006).

6. In 2012,11 percent of smallholders surveyed stated that bananas were their main source of income (Hillbom 2012a:672).

7. Women's insistence that they worked primarily to provide for their families has been supported by studies of East African household decision making. Market women surveyed by C.K. Omari in 1987 claimed to use business profits primarily to cover household expenses. The highest percentage of women's reported expenditures was directed toward school fees (52 percent), while other profits were saved for the future, invested in business, or used to purchase food (Omari 1996:117-18).

\section{Appendix: List of Interviewees Referenced}

Axwesso, Raheli, age 52, Lutheran pastor, Arusha, January 19, 2017.

Ezekiel, Veronica, age 65, farmer and entrepreneur, Manyata, October 6, 2016.

Kamasho (no first name given), age around late 30s, Lutheran pastor, Kilala, February 22, 2017.

Kinagazi, Rita, 59, teacher nearing retirement, Kilala, October 1, 2016.

Kitange, Grace, age 50, Lutheran parish worker, Moshi, November 25, 2016. Kitio, Loveness, age 51, entrepreneur, Kilala, January 21, 2017.

Kitomari, Abraham, age 47, Village chairman, self-employed, Singisi, January 23, 2017.

Kitomari, Robert Ndeleko, age 91, retired coffee farmer and former Meru Cooperative chairman, Singisi, November 1, 2016.

Mana, Stanley, age 37, unemployed at the time of our interview, previously worked in mining and tourism, Kofundi, November 21, 2016. 
Mbise, Margaret, age 66, retired teacher, Nkoranga, October 7, 2016.

Nasari, Elli, age 62, retired teacher, Singisi, January 6, 2017.

Ndosi, Moses, age 80, retired doctor, Njoro, December 7, 2016.

Pallangyo, Betseba, age 58, farmer, Kofundi, September 29, 2016.

Pallangyo, Eunice, late thirties, $\mathrm{PhD}$ candidate, raised in Meru, Kilala, January 21, 2017.

Pallangyo, Helena, age 33, entrepreneur (small shop), Kofundi, October 14, 2016.

Sarakikya, Martha, age 58, ambassador's wife, raised and retired in Meru, Nkoranga, December 27, 2016.

Urai, Elizabeth, age 63, hospital matron, Nkoranga, October 5, 2016. 